\title{
The Effect of the Width of a Peninsula to the Sea-breeze
}

\author{
By Shigeo Abe and Tadahiko Yoshida
}

Institute of Meteorology, Defense Academy, Yokosuka 239, Japan

(Manuscript received 8 July 1981, in revised form 28 August 1982)

\begin{abstract}
In Kanto area, Japan, the towering cumuli and cumulonimbi are often observed in a clear day of summer over Boso and Izu peninsulas, while over Miura peninsula such cumuli are never observed. In this study it was tried to investigate numerically the effects of peninsular width and thermal condition on the sea-breeze over a peninsula, using a two-dimensional model in the vertical plane.

Some interesting results are summarized as follows: (1) The strong ascending flow appears at the center of a peninsula in the evening, and is weakened rapidly corresponding with the increase of the peninsular width. (2) There is the peninsular width of about $30-50 \mathrm{~km}$ where the most preferable vertical velocity is observed, and the velocity reaches three times greater than that for the so-called sea-breeze. This width is equivalent to those of Boso and Izu peninsulas. (3) In the case of the large width crossing over $150 \mathrm{~km}$, the strong vertical motion such as stated in (1) disappears excepting that for the sea-breeze circulation which develops in daytime.
\end{abstract}

\section{Introduction}

Recently, the land and sea breeze which was well known as a remarkable meteorological phenomenon since last century has again been noted in relation to the problem of atmospheric diffusion. Though some observational results were proposed (Simpson et al., 1977; Fujibe et al., 1979; etc.), the profile of the phenomenon has, however, not been understood completely because of complex circumstances of the phenomenon. The recent development of electronic computer technique had led to be able to simulate the phenomenon, and it has been atempted to understand the profile inversely from the results of the simulation (Estoque, 1961; Neumann et al., 1971; etc.). From the computations for the horizontal orographic effect (McPherson, 1970; Pielke, 1974; Takano, 1976; etc.) and for the vertical orographic effect (Asai et al., 1978; Ookouchi et al., 1978; Kikuchi et al., 1981; etc.) to the land and sea breeze, it has been shown that there was the ascending flow region at $10 \mathrm{~km}$ inland across the coast, and the head of this region is sometimes termed the sea-breeze front.

While, it has been pointed out that there were the vertical flows intensified at the center of a peninsula (Takano, 1976). Actually, we observe sometimes in a clear day of summer the developed towering clouds over Boso and Izu peninsulas in Kanto district. However, they are scarcely observed over Miura peninsula. Though Neumann et al (1974) discussed on the heat low in a circular island, we try to study the effect of the peninsular width and the surface heating to the sea-breeze using a simple vertical twodimensional model.

\section{The model}

\subsection{The climatic and topographic model}

We treat the sea-breeze in the vertical two dimensional region making a land area as the peninsula whose width is variable $8 \sim 150 \mathrm{~km}$ (see Fig. 2). This range of the width contains Boso (about $50 \mathrm{~km})$, Izu $(30 \mathrm{~km})$ and Miura $(10 \mathrm{~km})$ peninsulas in South Kanto area in Japan.

We use the diurnal variations of the surface air temperature as a thermal boundary conditions on the land instead of a direct treatment of the surface heating. The surface temperature at Kannonzaki in Miura peninsula changes from $31.1^{\circ} \mathrm{C}$ (maximum) to $22.9^{\circ} \mathrm{C}$ (minimum) (from meteorological annual reports of Maritime SelfDefense Force, 1968) in August when the seabreezes are sometimes observed over South 
Table 1 The maximum and minimum temperatures represented by parameter $X$.

\begin{tabular}{ccc}
\hline$X$ & $\operatorname{Max}\left({ }^{\circ} \mathrm{C}\right)$ & $\operatorname{Min}\left({ }^{\circ} \mathrm{C}\right)$ \\
\hline 1 & 31.1 & 22.9 \\
$5 / 6$ & 30.1 & 23.3 \\
$2 / 3$ & 29.1 & 23.6 \\
$1 / 2$ & 28.1 & 24.0 \\
\hline
\end{tabular}

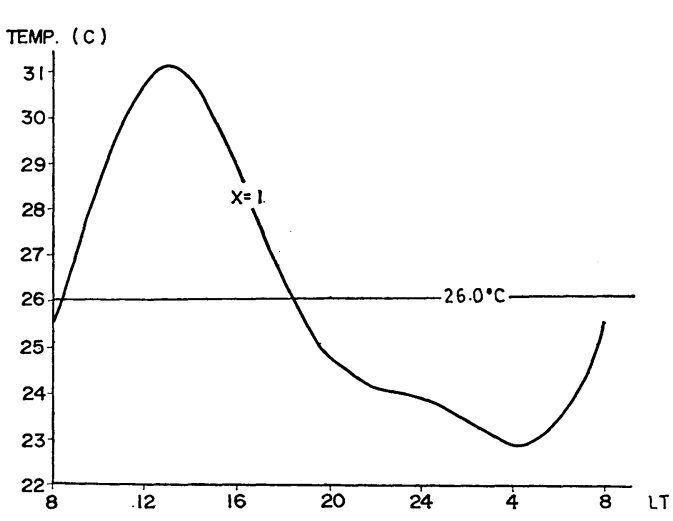

Fig. 1 Diurnal variation of surface temperature. Thin line shows sea surface temperature.

Kanto. Referring the above data, we assume the diurnal variations of temperature as follows:

$$
\begin{gathered}
\theta_{\text {Land }}=\theta_{s s}+\left\{1.05+3.75 \sin \left(\frac{15 t}{3600}+6\right)\right. \\
\left.+1.28 \sin \left(\frac{30 t}{3600}+310\right)\right\} X
\end{gathered}
$$

where $X$ is a parameter representing the diurnal temperature difference $(t=0$ shows the value at $08.00 \mathrm{LT}$ ). We carried out four cases for various $X$ as shown in Table 1. (2.1.1) as shown in Fig. 1 is the same with the equation adopted by Neumann et al. (1971) for Israel, excepting the magnitude and inland temperature gradient.

While, the sea surface temperature is assumed to be constant $\left(\theta_{s s}=26^{\circ} \mathrm{C}\right)$, because its diurnal variations are less than $1{ }^{\circ} \mathrm{C}$ from the annual reports shown above.

\subsection{Basic equations system}

The basic equations are reduced to the so called anelastic equations system using Boussinesque approximation and hydrostatic equilibrium by making an order estimations for characteristic scales of the sea-breeze. The effect of water vapour is not included in the system for simplicity. Assuming the system which is uniform along the $y$-direction $(\partial / \partial y=0)$, we obtain the following equations for the deviations from the state of hydro-static equilibrium (indicated by subscripts $s$ ):

$$
\begin{aligned}
& \frac{\partial u}{\partial t}+u \frac{\partial u}{\partial x}+w \frac{\partial u}{\partial z}=-\theta_{t} \frac{\partial \pi}{\partial x} \\
& +f v+\frac{\partial}{\partial z}\left(K_{M} \frac{\partial v}{\partial z}\right), \\
& \frac{\partial v}{\partial t}+u \frac{\partial v}{\partial x}+w \frac{\partial v}{\partial z}=-f u+\frac{\partial}{\partial z}\left(K_{M} \frac{\partial v}{\partial z}\right), \\
& \frac{\partial \pi}{\partial z}=\frac{g}{\theta_{s}^{2}} \cdot \theta, \\
& \frac{\partial u}{\partial x}+\frac{\partial w}{\partial z}=0, \\
& \frac{\partial \theta}{\partial t}+u \frac{\partial \theta}{\partial x}+w \frac{\partial \theta}{\partial z}=-w \frac{\partial \theta_{s}}{\partial z}+\frac{\partial}{\partial z}\left(K_{H} \frac{\partial \theta}{\partial z}\right)
\end{aligned}
$$

where

$$
\pi=c_{p}\left(\frac{p}{p_{0}}\right)^{R / c_{p}}
$$

Eqs. (2.2.1) and (2.2.2) are the horizontal components of equation of motion. Eqs. (2.2.3), (2.2.4) and (2.2.5) are the hydrostatic relation, the equation of continuity and the equation of heat energy, respectively. Eq. (2.2.6) is Exner function, and other symbols are listed in Appendix Table. Besides, $\partial \theta_{s} / \partial_{z}=0.38^{\circ} \mathrm{C} / 100 \mathrm{~m}$ is adopted as a stability of the standard atmosphere.

Next, we shall note some cautions for carrying out the computations.

\section{(1) Grid}

The computational region, whose right side is regarded as the center of a peninsula by applying the symmetry of the simulated model, extends to $128 \mathrm{~km}$ for $x$-direction and to $2.95 \mathrm{~km}$ for $z$-direction (see Fig. 2). The staggerd grids system is used and the grid distance is taken as $4 \mathrm{~km}$ to $x$-direction and $100 \mathrm{~m}$ to $z$-direction except for the first grid point which is located at $50 \mathrm{~m}$ above the ground.

\section{(2) Vertical diffusion}

The turbulent transfer of heat and momentum, as a diffusion process, is taken into account by introducing the different coefficients for stable and unstable stratifications, separately. When the equation of KEYPS (Yamamoto, 1959) is used, the eddy coefficient for momentum is given by 


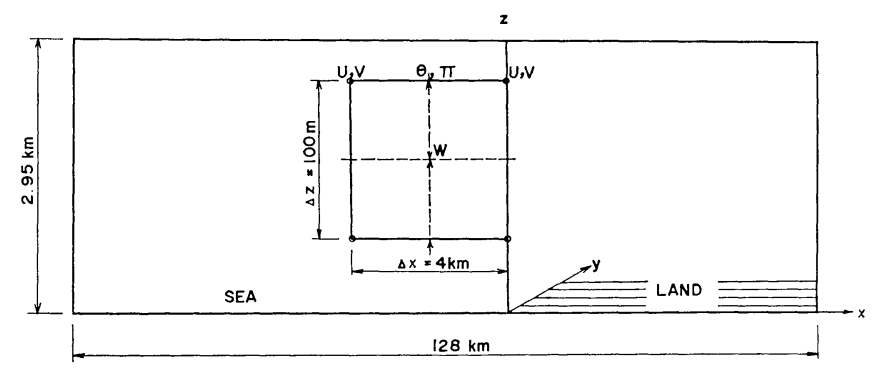

Fig. 2 Computational region and grid configuration.

$$
\left.K_{M}=l^{2}\left\{\left(\frac{\partial u}{\partial z}\right)^{2}+\alpha \frac{g}{\theta_{a}}\left|\frac{\partial \theta_{0}}{\partial z}\right|\right)\right\}^{1 / 2},
$$

where $\alpha=K_{H} / K_{M}$ is assumed to 1 because of $K_{H} \fallingdotseq K_{M}$ in the atmosphere, and $l$ and $\theta_{a}$ are the mixing length and the representative potential temperature in a diffusion area, respectively. The first term in (2.2.7); the vertical shear of a zonal flow, is neglected as it is much smaller than the second stability term. We assume that $l$ is constant in the atmosphere and is decided to $50 \mathrm{~m}$ by the convective instability considerations (see Ookouchi et al., 1978). Thus, when the stratification becomes unstable, $K_{M}$ or $K_{H}$ in the transition layer above $z=50 \mathrm{~m}$ is shown as follows, using $\theta_{a}=302^{\circ} \mathrm{K}$ as the representative potential temperature in the middle layer of the model:

$$
\begin{aligned}
K_{M} & =K_{H} \\
& = \begin{cases}2500\left(\frac{9.8}{302}\left|\frac{\partial \theta_{0}}{\partial z}\right|\right)^{1 / 2} \geqq 5 \mathrm{~m}^{2} / \mathrm{s} & \left(\frac{\partial \theta_{0}}{\partial z}<0\right) \\
5 \mathrm{~m}^{2} / \mathrm{s} & \left(\frac{\partial \theta_{0}}{\partial z}>0\right) .\end{cases}
\end{aligned}
$$

\section{(3) Horizontal diffusion}

Shuman's smoothing method (1957) is used instead of treating directly the horizontal diffusion term to suppress the effects of horizontal small scale waves of the same order of grid distance. In Shuman's method, $\phi_{i}$ indicating a variable at a grid point $i$, is replaced

$$
\bar{\phi}_{i}=(1-s) \phi_{i}+s \frac{\phi_{i+1}+\phi_{i-1}}{2},
$$

where $s$ is a smoothing element. In the present study, $s$ is selected to 0.02 as a value equivalent to a horizontal eddy diffusion coefficient: 2700 $\mathrm{m}^{2} / \mathrm{s}$.

\subsection{Initial and boundary conditions (1) Initial conditions}

The initial atmosphere is at rest $(u, v, \pi, \theta=0)$, then the potential temperature in each level is given as follows:

$$
\theta_{s}=\theta_{s s}+\frac{\partial \theta_{s}}{\partial z} z=\theta_{s s}+0.0038 z
$$

\section{(2) Boundary conditions}

We take the computational region as shown in Fig. 2 which is a plane perpendicular to the coastal line of a peninsula and the right side of the region is the center of a peninsula. Thus, the distributions of $w, \pi, \theta, K_{M}$ and $K_{H}$ are symmetry and $u$ and $v$ are anti-symmetry at the right side of the region.

i) Kinematic and dynamic boundary conditions

Non-slip boundary condition is assumed on the land and sea surfaces

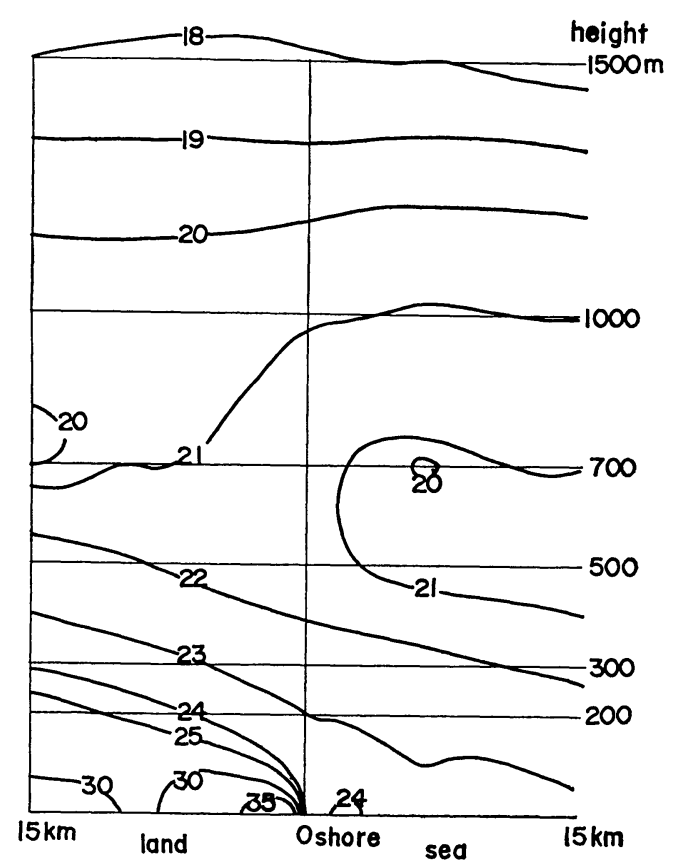

Fig. 3 Temperature distributions $\left({ }^{\circ} \mathrm{C}\right)$ measured on a light plane above the coastal area near Kashima city around 12.00 13.15 JST, Aug. 22, 1974. (after Yoshikado) 


$$
u, v, w=0,
$$

and on the upper boundary,

$$
u, v, \pi, \theta=0 \quad \text { at } \quad z=2950 \mathrm{~m} \text {, }
$$

because of no basic flow. At the left side wall, we assume

$$
\partial / \partial x(u, v, \pi, \theta)=0 \text { and } w=0 .
$$

This means that there is no friction along the boundary and computational region is open. At the right side wall, it is assumed that

$$
u, v=0 \text { and } \partial w / \partial x=0
$$

from the condition of symmetry (see Fig. 2).

ii) Thermal boundary conditions

As noted in Section 2.1, the temperature on the ground is given by (2.1.1) and that on the sea surface is constant $\left(\theta_{s s}=26^{\circ} \mathrm{C}\right)$. The temperature distribution near the coast gives considerable effects to the sea-breeze circulation.
There is an example of the observation which was measured on a light plane over Kashima city in Kanto district as shown in Fig. 3 (by Yoshikado, 1975). The large temperature gradient spread to $10 \mathrm{~km}$ inland excepting the lowest layer near the coast and the gradient between inland and the coast is estimated to about $5^{\circ} \mathrm{C} /$ $10 \mathrm{~km}$. Therefore, it would be suitable in our model to change linearly the surface temperature between the coast and the inland point which is $12 \mathrm{~km}$ apart from the coast.

\section{Computational results}

\subsection{General sea-breeze}

First, we show the general example which takes the most suitable diurnal variation of temperature in the model of August in Kanto area $(X=2 / 3$, see Table 1$)$ and sufficiently wide peninsula (width: $152 \mathrm{~km}$ ) producing no strong

(a) $\mathrm{L}$

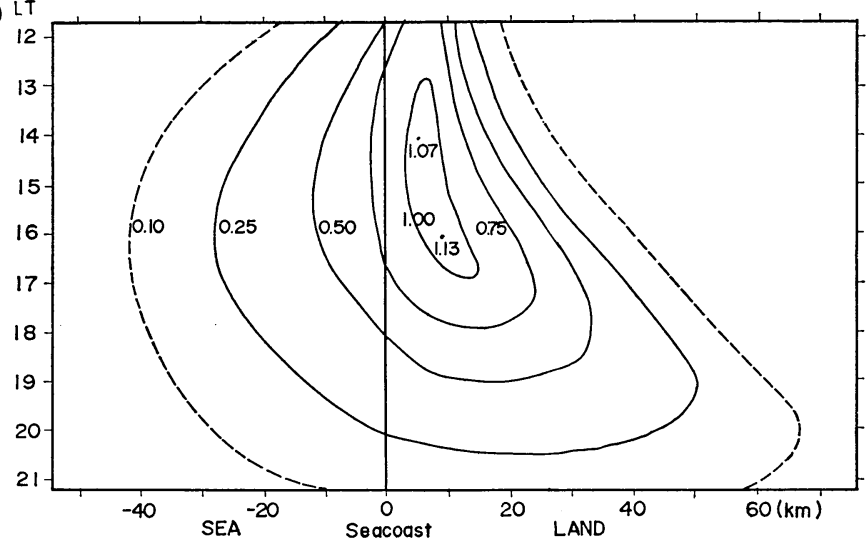

(b) $\mathrm{L}$

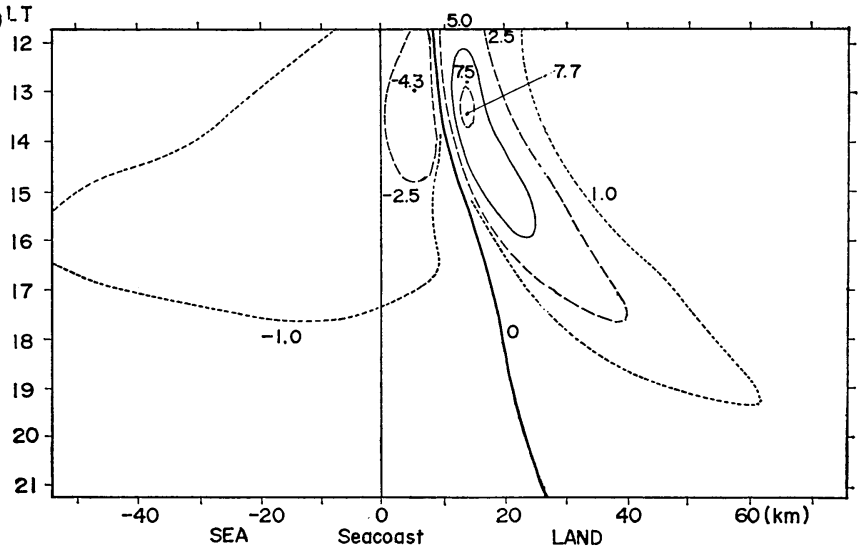

Fig. 4 Time-horizontal scale diagrams of $u(\mathrm{~m} / \mathrm{s})$ at $50 \mathrm{~m}$ height (a) and $w(\mathrm{~cm} / \mathrm{s})$ at $600 \mathrm{~m}$ height (b). $(X=2 / 3$, peninsular width: $152 \mathrm{~km})$. 

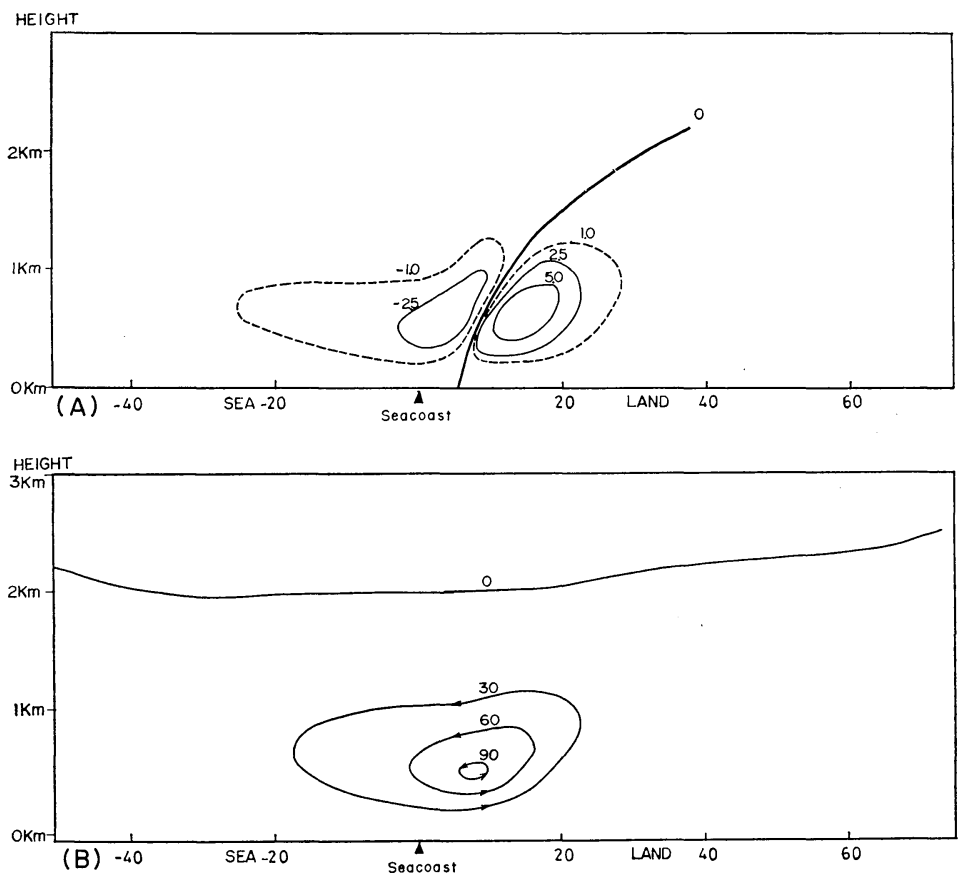

Fig. 5 Fields of $w(\mathrm{~cm} / \mathrm{s}):(\mathrm{A})$ and stream line $\left(10 \mathrm{~m}^{2} / \mathrm{s}\right):(\mathrm{B})$ are shown on the case of $X=2 / 3$ and the width: $152 \mathrm{~km}$ at $13.30 \mathrm{LT}$. Right side corner is the center of peninsula.
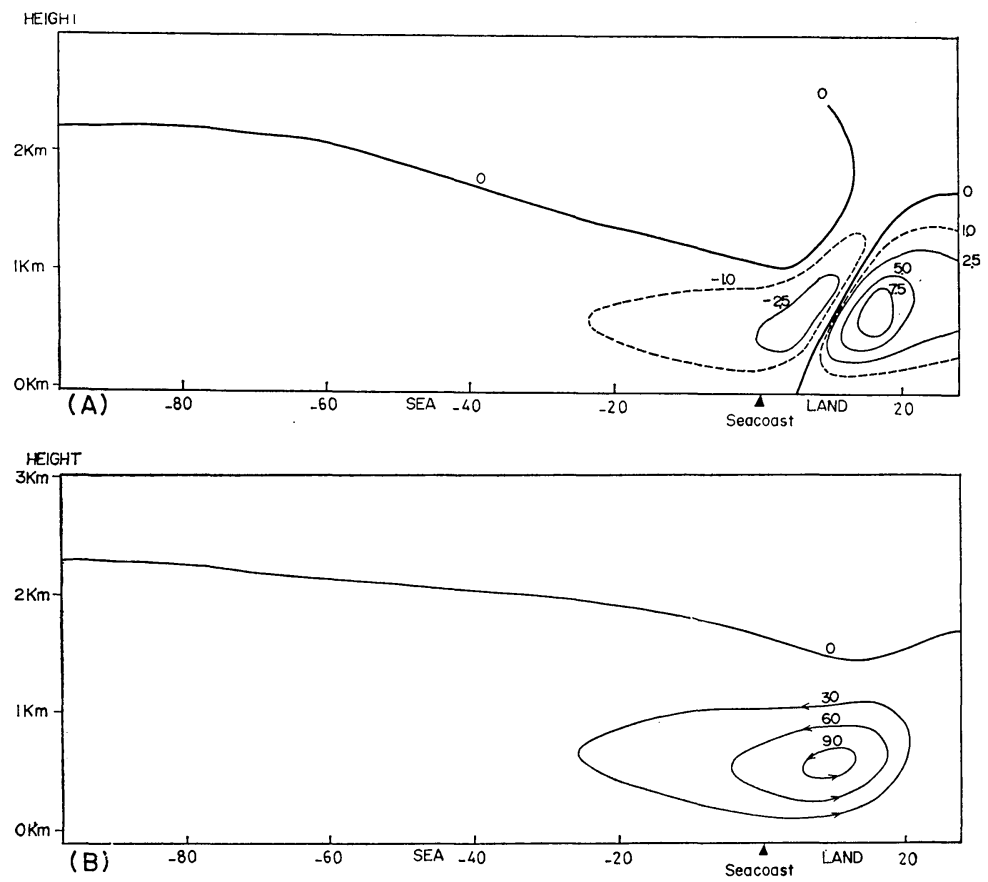

Fig. 6 Same as Fig. 5, but for $X=2 / 3$ and the width: $56 \mathrm{~km}$ at 14.15 LT. 
(a)

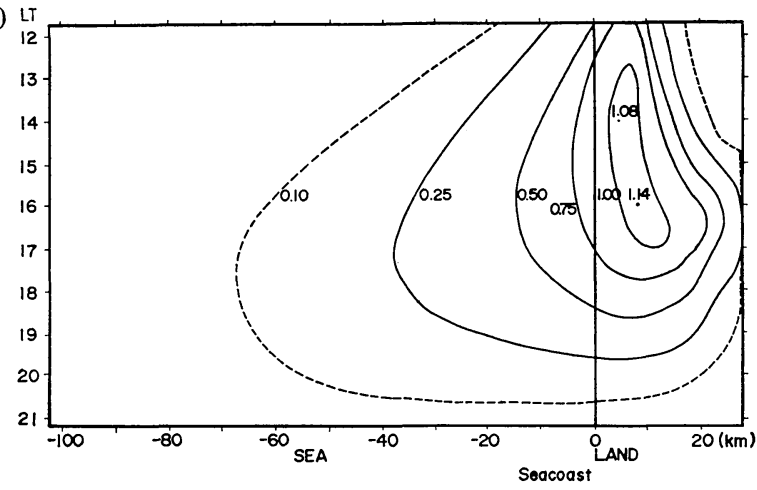

(b)

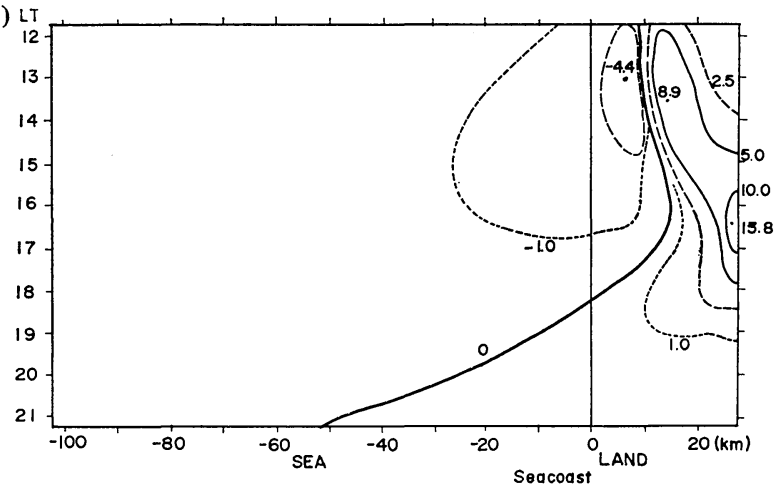

Fig. 7 Time-horizontal scale diagrams of $u$ and $w$. Same as Fig. 4, but for $X=2 / 3$ and peninsular width: $56 \mathrm{~km}$.

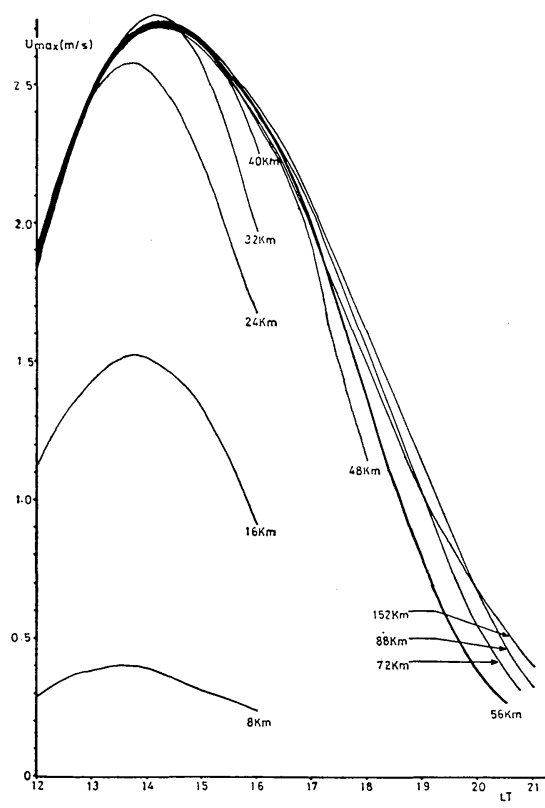

Fig. 8 Time variation of maximum $u$ in the computational region in each peninsular width for $X=2 / 3$ case.

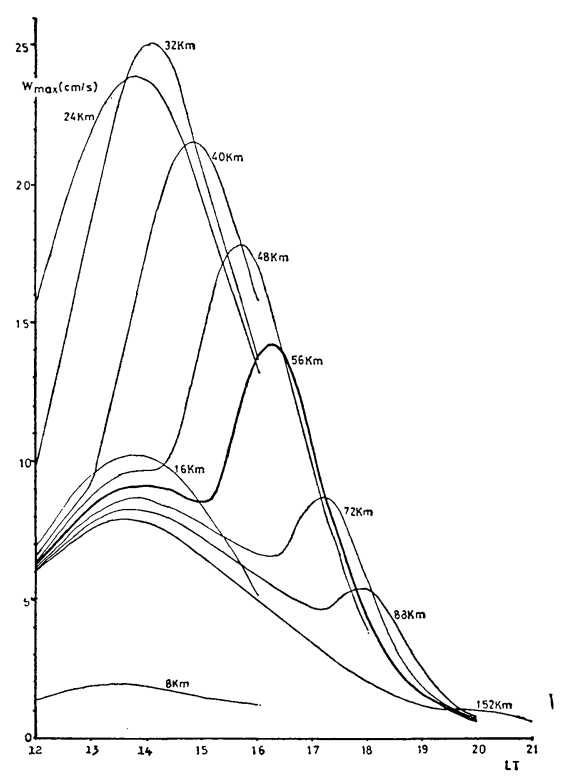

Fig. 9 Same as Fig. 8, but for maximum $w$. 
ascending flow at the center of it. We will note the distributions of $u$ and $w$ to investigate the convergence effect at the center of the peninsula.

The $x-t$ cross-sections of $u$ at $50 \mathrm{~m}$ height and $w$ at $600 \mathrm{~m}$ height are shown in Fig. 4. The axes of $u_{\max }$ and $w_{\max }$ are placed almost at constant distance from the coast till near 14.00 LT. However, after $14.00 \mathrm{LT}$, the axes travel to inland acceleratedly. The profile of the sea-breeze circulation in which the maximum $w$ is observed at $13.30 \mathrm{LT}$ is shown in Fig. 5. The center of circulation exists $8 \mathrm{~km}$ inland across the coast at the height of $500 \mathrm{~m}$ and the top of the circulation cell reachs to $2000 \mathrm{~m}$.

\subsection{The effects of the peninsular width}

We examine the case of narrow width; $56 \mathrm{~km}$, and compare with the results in the last subsection. The profile of the circulation at 14.00 LT is shown in Fig. 6. The maximum value of $w$ is greater about $20 \%$ than in the wide width case in spite of the same $X$ value $(2 / 3)$. As shown in Fig. 7, the axis of $u_{\max }$ travels to inland after $14.00 \mathrm{LT}$, but it starts to return seaward after $17.00 \mathrm{LT}$. This tendency is distinct particularly for $w$, as if wave is reflected at the center of a peninsula.

Next, the time variations of $u_{\max }$ in the computational region are shown in Fig. 8 for various peninsular widths. The values of $u_{\max }$ in the case of comparatively narrow width are small because of the little heating surface. In the wide width crossing over $48 \mathrm{~km}$, their extreme values converge to a constant $(2.7 \mathrm{~m} / \mathrm{s})$ and is observed near $14.00 \mathrm{LT}$ when the temperature difference between the sea and the land is near to its maximum. Thereafter $u_{\max }$ dectreases consistently with the reduction of the temperature difference.

Fig. 9 shows the time variations of $w_{\max }$ drawn in the same manner with Fig. 8. The profiles

(a)

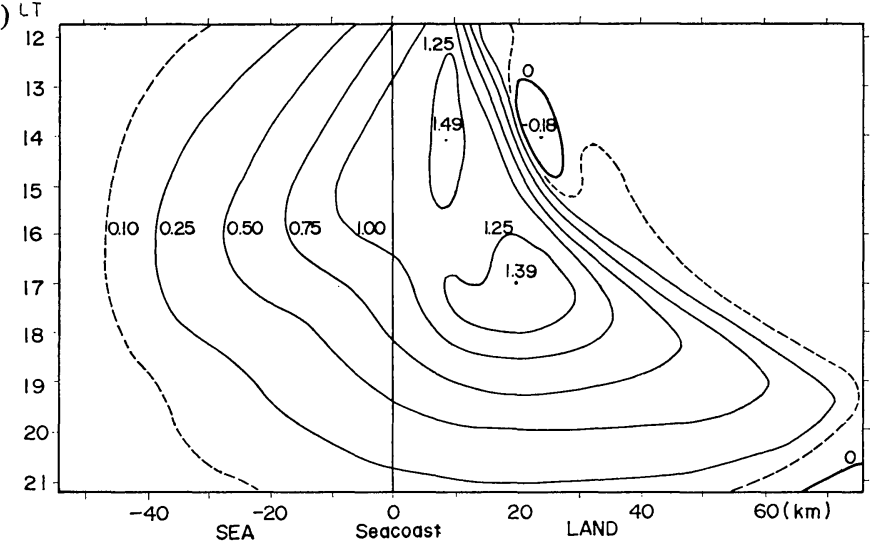

(b) $\mathrm{L}$

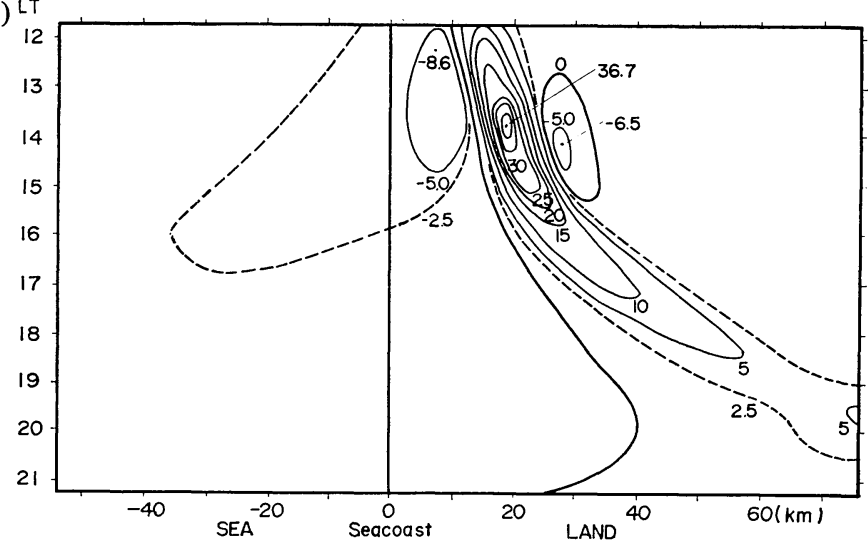

Fig. 10 Time-horizontal scale diagrams of $u$ and $w$. Same as Fig. 4, but for $X=1$ and peninsular width: $152 \mathrm{~km}$. 

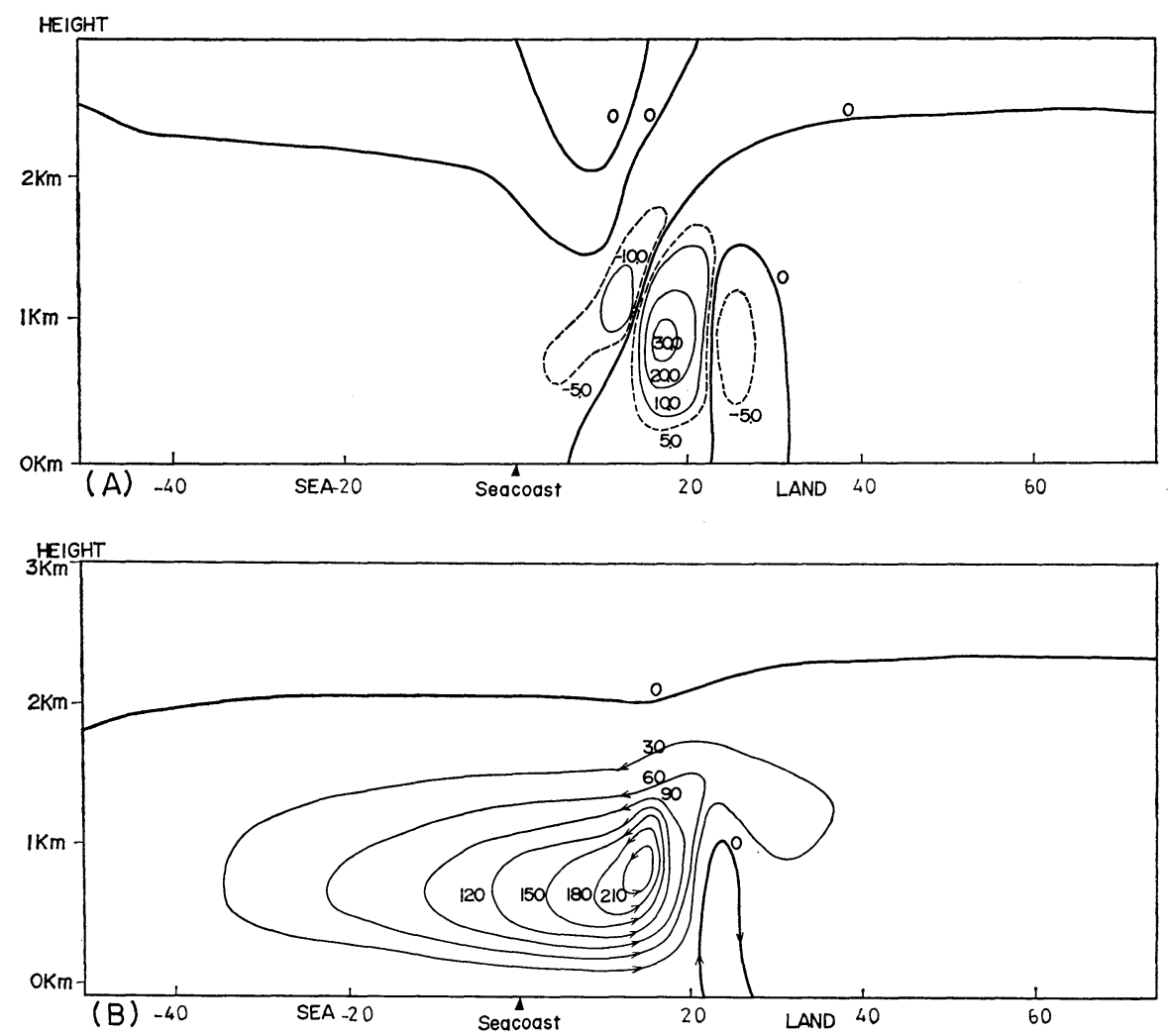

Fig. 11 The field of $w$ and stream lines at 14.15 LT. Same as Fig. 5, but for $X=1$ and peninsular width: $152 \mathrm{~km}$.

of $w_{\max }$ are much different from those of $u_{\max }$. The extreme value of $w_{\max }$ is observed only one near $14.00 \mathrm{LT}$ in the case of narrow peninsula under $40 \mathrm{~km}$. But for the wide width crossing over $40 \mathrm{~km}$, there are two extreme values: the one changes its magnitude and its observed time with increase of the width, the other is a constant $w_{\max }$ of about $8 \mathrm{~cm} / \mathrm{s}$ observed near 14.00 LT in spite of the increase of the width. Furthermore, it is noticed in medium width cases that the extreme value in the evening is greater than that in daytime.

\subsection{Secondary circulation}

In this section, we investigate the modification of the sea-breeze for the change of parameter $X$ in the case of wide peninsula $(152 \mathrm{~km})$. In the case of $X=1$ as shown in Fig. 10, the secondary circulation of the sea-breeze is found definitely about $14.00 \mathrm{LT}$ when the surface temperature becomes maximum, and thereafter the axes of $u_{\max }$ and $w_{\max }$ move inland rapidly as same as smaller $X$ cases. The secondary circulation which is pointed out by Yoshikado (1976) is scarsely observed in the real sea-breeze, and its existence has still been not confirmed. In Fig. 11, the example of computed secondary circulation at 14.15 LT is shown as a most intensified case. According to Yoshikado, the secondary circulation develops due to a degree of the surface heating or horizontal diffusion coefficient. From the fact, the result in Fig. 11 would be a kind of heat convection due to strong surface heating rather than the effect of the peninsular width. Naumann et al. (1974) discribed the sea-breeze in a circular island using a system of nonhydrostatic equilibrium. In the large diurnal temperature differences $\left(24^{\circ} \mathrm{C}\right)$, the circulation named the formation of 'eye' near the center of the island seems to be corresponding with the above secondary circulation.

\section{Discussions}

In the last section, we recognized the two extreme values of $w_{\max }$ in time sequence as shown in Fig. 9. It will be investigated in this section whether the peak of $w_{\max }$ affceted by the peninsular width can be explained by the convergence of the breeze from both side coasts. 


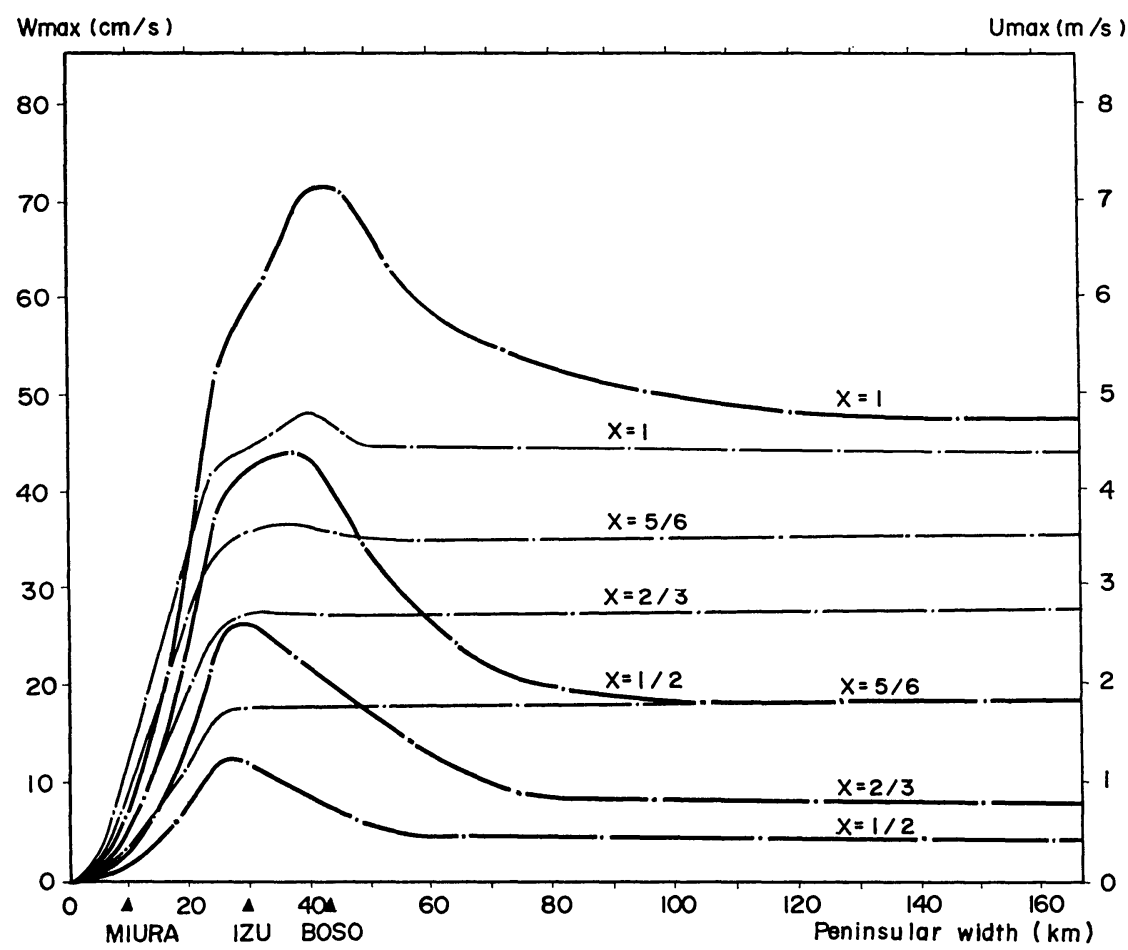

Fig. 12 The distributions of $u_{\max }$ and $w_{\max }$ related with peninsular width in each $X$.

\section{(1) Penetration of the sea-breeze}

As seen in Section 3.1, there is the peak of $14.00 \mathrm{LT}$. After $14.00 \mathrm{LT}$, the axis of $w_{\max }$ begins to move inland acceleratedly, and its mean moving speed between $14.00 \mathrm{LT}$ and $20.00 \mathrm{LT}$ is $3 \mathrm{~m} / \mathrm{s}$ from Fig. 4(b), specially after $19.00 \mathrm{LT}$ $4.0 \mathrm{~m} / \mathrm{s}$ over. These values are larger than $u_{\max }$. Moreover, it is noticed that the advance is accelerated in spite of the decreasing of $u_{m \times a}$ in the evening. The fact shows that the axis of $w_{\max }$ is not transported by horizontal flow itself.

(2) The existence of preferable peninsular width for the largest $w_{\max }$

In Fig. 12, the changes of $u_{\max }$ and $w_{\max }$ are shown as a function of the peninsular width for each $X$. It is of interest that there is the preferable scale of $30 \sim 50 \mathrm{~km}$ in the peninsular width where a large value of $w_{\max }$ is observed. In the large width, $w_{\max }$ decreases again and at last converges to a constant. In $X=2 / 3$, the former is greater over three times than the latter. The $30 \sim 50 \mathrm{~km}$ width is just coincide with that of Izu and Boso peninsulas. There will be sufficient possibility of convective circulation over the peinsula, if the effect of latent heat or the oro- graphy be taken into account even in the smaller $X$ cases.

In fact, in Kanto district, towering cumuli or cumulo-nimbi are sometimes observed over Boso and Izu peninsulas or Abukuma and Mikuni mountaines in a clear day of summer. While, those clouds are scarecely observed over Miura peninsula. Although the clouds in a local inland circulation may be affected by the mountain and valley wind, the mountaines in Boso peninsula are not so high $(200 \sim 400 \mathrm{~m})$ that it is difficult to consider the cause for the generation of convective clouds only by the mountains.

\section{Conclusions}

According to the vertical two dimensional simulation of a peninsula using the climatic data as near as possible middle August of Kanto, we obtained some interesting results as follows:

(1) The ascending flow developed before 14.00 LT is due to the circulation of the land and sea breeze generated by the temperature gradient at the coast, and the position of maximum ascending flow is almost constant at $14 \mathrm{~km}$ inland. This ascending flow moves inland with decreasing its value, and increases again at the 
center of a peninsula. This $w_{\max }$ develops after 14.00 LT and the time of its appearance becomes later corresponding with increasing of the peninsular width.

(2) The width of the peninsula where the most preferable $w_{\max }$ observed at the center is $30 \sim$ $50 \mathrm{~km}$, and is corresponding to Bose and Izu peninsulas. In these cases of $X=2 / 3$, the maximum of $w_{\max }$ is greater over three times than that in the general sea-breeze. Thus if the influences of a vapour and topographical confiugrations are taken into considerations, the effect stated above would be more distinct and will contribute to the development of towering clouds or cumulo-nimbi.

(3) The effect of a peninsula is not so remarkable in the case of the large width (over $150 \mathrm{~km}$ ) that the ascending flow at the peninsular center disappears and the so called sea-breeze only is observed.

\section{Acknowledgements}

We are grateful to Dr. Uryu and Dr. Ookouchi for their many valuable suggestions and to the library of the geophysical institute of Tokyo university for many helps in order to searching of the references. We are also much appreciating Dr. Ohnishi for his encouragement. The computations were performed by NEAC2000 at Defense Academy Computer Center.

\section{Appendix}

\section{Definition of Symbols}

$c_{p}$ : Specific heat of dry air $(1000 \mathrm{~J} / \mathrm{kg} . \mathrm{deg})$

$f:$ Coriolis' parameter $(1.2,10 / \mathrm{sec})$

$g:$ Acceleration of gravity $(9.8 \mathrm{~m} / \mathrm{s})$

$K_{H}$ : Eddy diffusion coefficient of heat

$K_{M}$ : Eddy diffusion coefficient of momentum

$l:$ Mixing length

$R:$ Gas constant for dry air $(287 \mathrm{~J} / \mathrm{kg}$. deg $)$

$t:$ Time (second)

$u$ : Velocity component in $x$-direction

$u_{\max }:$ Maximum horizontal velocity in the computational region at each time step

$v:$ Velocity component in $y$-direction

$w$ : Velocity component in $z$-direction

$w_{\max }:$ Maximum vertical velocity in the computational region at each time step

$X$ : Parameter representing the diurnal temperature difference

$\theta_{t}$ : Potential temperature at time $t$

$\theta:$ Deviation of potential temperature from the initial static state $\theta_{a}$ : Constant representative potential temperature

$\theta_{\text {Land }}:$ Potential temperature at the land surface

$\theta_{s}:$ Initial potential temperature

$\theta_{s s}$ : Potential temperature on the sea surface

$\pi_{s}:$ Exner function

$\pi$ : Deviation of Exner function from reference static state

\section{References}

Asai, T. and S. Mitsumoto, 1978: Effects of an inclined land and sea breeze circulation: A numerical experiment, J. Meteor. Soc. Japan, 56, 559-570.

Estoque, M. A., 1961: A theoretical investigation of the sea breeze, Quart. J. Roy. Meteor. Soc., 87, 136-146.

Fujibe, F. and T. Asai, 1979: A study of local wind in Kanto District (in Japanese), Tenki, 26, 595604.

Hsu, S. A., 1970: Coastal air circulation system: Observations and empirical model, Month. Wea. Rev., 98, 487-509.

Kikuchi, Y., S. Arakawa, F. Kimura, K. Shirasaki and Y. Nagano, 1981: Numerical study on the effects of mountains on the land and sea breeze circulation in the Kanto District, J. Meteor. Soc. Japan, 59, 723-738.

McPherson, R. D., 1970: A numerical study of the effect of a coastal irregularity in the sea breeze, J. Appl. Meteor., 9, 767-777.

Moroz, W. J., 1967: A lake breeze on the eastern shore of Lake Michigan: Observations and model, J. Atmos. Sci., 24, 337-355.

Neumann, J. and Y. Mahrer, 1971: A theoretical study of the land and sea breeze circulation, $J$. Atmos. Sci., 28, 532-542.

- 1974: A theoretical study of the sea and land breezes of circular islands, J. Atmos. Sci., 31, 2027-2039.

Ookouchi, Y., M. Uryu and R. Sawada, 1978: A numerical study of the effects of a mountain on the land and sea breeze, J. Meteor. Soc. Japan, 56, 368-386.

Pielke, R. A., 1974: A three-dimensional numerical model of the sea breeze over South Florida, Mon. Wea. Rev., 102, 115-139.

Shuman, F. G., 1957: Numerical methods in weather prediction: smoothing and filtering, Mon. Wea. Rev., 85, 357-361.

Simpson, J.E., D. A. Mansfield and J. R. Milford, 1977: Inland penetration of sea-breeze fronts, Quart. J. Roy. Meteor. Soc., 103, 47-76.

Takano, K., 1976: Three dimensional numerical modeling of the land and sea breeze and the urban heat island in the Kanto Plain, Dr. Sci. Thesis, Tokyo Univ.

Yamamoto, G., 1959: Theory of turbulent transfer 
in non-neutral conditions, J. Meteor. Soc. Japan, 37, $60-70$.

Yoshikado, H., M. Gamou and O. Yokoyama, 1975: Observation of the sea breeze in Kashima area (in Japanese), Kogai, 10, 227-235.

Yoshikado, H., 1976: On the horizontal scale of the sea-breeze (in Japanese), Kogai, 11, 307-319.

\section{海陸風に及ぼす半島幅の効果}

\section{阿部 成 雄・吉田 忠 彦 \\ 防衛大学校地学教室}

関東地方の房総・伊豆半島には夏の晴れた日に, しばしば雄大積雲が発達するが, 三浦半島ではこのよらなこ とはない。そこで我々は半島上の海陸風に扣よぼす半島幅や熱的効果について数值実験を試みた。

その結果次のようなことがわかった。

（1）半島中央部では海陸風の発達は14時頃よりむしろ夕刻に上昇流の最大が現われる。そしてこの上昇速度は 半島幅の增加と共に急速に減衰する。

（2）上昇流が最も強く現われる半島幅が存在し，それは 30 50 km でその強さはいわゆる海陸風による上昇 流の 3 倍にも達する。この半島幅は房総・伊豆半島の幅に相当する。

（3）半島幅の効果が消えるのは幅約 $150 \mathrm{~km}$ 以上の場合で，この時はいわゆる海陸風のみが現われる。 